\title{
Dethiosulfovibrio peptidovorans gen. nov., sp. nov., a New Anaerobic, Slightly Halophilic, Thiosulfate-Reducing Bacterium from Corroding Offshore Oil Wells
}

\author{
M. MAGOT, ${ }^{1}$ G. RAVOT, ${ }^{2}$ X. CAMPAIGNOLLE ${ }^{3}$ B. OLLIVIER, ${ }^{2 *}$ B. K. C. PATEL ${ }^{4}$ \\ M.-L. FARDEAU, ${ }^{2}$ P. THOMAS, ${ }^{5}$ J.-L. CROLET, ${ }^{6}$ AND J.-L. GARCIA ${ }^{2}$ \\ Sanofi Recherche, 31676 Labège Cedex, ${ }^{1}$ Laboratoire ORSTOM de Microbiologie des Anaérobies, Université de \\ Provence, ${ }^{2}$ and Département de Biologie, Université de la Méditerranée, ${ }^{5} 13288$ Marseille Cedex 9, and \\ Laboratoire d'Océanologie Biologique, 33120 Arcachon, $^{3}$ and Elf Aquitaine Production, \\ 64018 Pau, ${ }^{6}$ France, and School of Biomolecular and Biomedical Sciences, \\ Griffith University, Nathan, Brisbane, 4111 Australia $^{4}$
}

\begin{abstract}
A strictly anaerobic thiosulfate-reducing bacterium was isolated from a corroding offshore oil well in Congo and was designated strain SEBR $4207^{\mathrm{T}}$. Pure culture of the strain induced a very active pitting corrosion of mild steel, with penetration rates of up to $4 \mathrm{~mm}$ per year. This constitutes the first experimental evidence of the involvement of thiosulfate reduction in microbial corrosion of steel. Strain SEBR $4207^{\mathrm{T}}$ cells were vibrios ( 3 to 5 by $1 \mu \mathrm{m}$ ), stained gram negative, and possessed lateral flagella. Spores were not detected. Optimum growth occurred in the presence of $3 \% \mathrm{NaCl}$ at $\mathrm{pH} 7.0$ and $42^{\circ} \mathrm{C}$. Strain SEBR $4207^{\mathrm{T}}$ utilized peptides and amino acids, but not sugars or fatty acids. It fermented serine, histidine, and Casamino Acids, whereas arginine, glutamate, leucine, isoleucine, alanine, valine, methionine, and asparagine were only used in the presence of thiosulfate. Peptides were fermented to acetate, isobutyrate, isovalerate, 2-methylbutyrate, $\mathrm{H}_{2}$, and $\mathrm{CO}_{2}$. The addition of either thiosulfate or sulfur but not sulfate increased peptide utilization, growth rate, and biomass; during growth, $\mathrm{H}_{2} \mathrm{~S}$ was produced and a concomitant decrease in $\mathrm{H}_{2}$ was observed. The addition of either thiosulfate or sulfur also reversed $\mathrm{H}_{2}$ inhibition. 16S rRNA sequence analysis indicates that strain SEBR $4207^{\mathrm{T}}$ is distantly related to members of the genus Thermoanaerobacter (83\% similarity). Because the phenotypic and phylogenetic characteristics cannot be assigned to any described genus, strain SEBR $4207^{\mathrm{T}}$ is designated as a new species of a new genus, Dethiosulfovibrio peptidovorans gen. nov., sp. nov. Strain SEBR $4207^{\mathrm{T}}$ has been deposited in the Deutsche Sammlung von Mikroorganismen und zellkulturen GmbH (= DSM 11002).
\end{abstract}

In 1989, Elf Congo experienced corrosion of the first $5 \mathrm{~km}$ of a $23-\mathrm{km}$ main subsea pipeline that transported sour oil (i.e., $\mathrm{H}_{2} \mathrm{~S}$-containing petroleum) produced from the Emeraude oil field. The corroded segment was replaced, but it corroded again a year later. The whole line was then replaced and operated under a specifically designed biocide treatment regimen. The preliminary examination of the corroded iron showed that the breakthrough was due to bacterial pitting corrosion, with an unusually high penetration rate of about 1 $\mathrm{cm}$ per year. Chemical analysis of the pipeline water revealed the presence of up to $0.5 \mathrm{mM}$ thiosulfate. It is likely that the thiosulfate was produced as a result of oxidation of the $\mathrm{H}_{2} \mathrm{~S}$ naturally present in the oil field ecosystem by oxygen that is introduced in the pipelines during processing $(10,15,22)$. The corrosion of pipelines was suspected to be due not only to sulfate but also to thiosulfate reduction by sulfate-reducing bacteria (SRB), because computer modeling had shown that thiosulfate reduction could induce the pitting corrosion of steel at higher rates than sulfate reduction (13).

Since the pipeline was under a biocide treatment regimen during our microbiological investigations, the production fluids from several wellheads upstream of the line were collected and analyzed. Besides different SRB species (42), several strains of

* Corresponding author. Mailing address: Laboratoire ORSTOM de Microbiologie des Anaérobies, Université de Provence, CESBESIL, Case 925, 163 Avenue de Luminy, 13288 Marseille Cedex 9, France. Phone: 334918285 76. Fax: 334918285 70. E-mail: ollivier @orstom.esil.univ-mrs.fr. non-sulfate-, thiosulfate-reducing anaerobic bacteria were isolated. We report here on the characterization of one of these strains that induced intense pitting corrosion of mild steel in the presence of thiosulfate. This strain represents a new genus of the domain Bacteria, Dethiosulfovibrio peptidovorans gen. nov., sp. nov.

(Part of this work was presented at the Annual Meeting of the American Society of Microbiology, New Orleans, La., 19 to 23 May 1996 [29].)

\section{MATERIALS AND METHODS}

Sample collection and sample source. Strain SEBR $4207^{\mathrm{T}}$ was isolated from the Emeraude oil field, which is an offshore oil-producing well (BB325, Congo) Water samples were aseptically collected as described previously (2). The in situ temperature of the oil field was $38^{\circ} \mathrm{C}$, and the total salinity was $52 \mathrm{~g} /$ liter.

Bacterial counts. Acridine orange direct counting was used to determine the total number of bacterial cells in the sample (21). Cultivable bacteria were enumerated by the three-tube most-probable-number (MPN) procedure. A saline solution was used for the preparation of all culture media in order to mimic the composition of the reservoir water. It contained (per liter) $13 \mathrm{mg}$ of $\mathrm{SrCl}_{2}$, $3.907 \mathrm{~g}$ of $\mathrm{MgCl}_{2} \cdot 6 \mathrm{H}_{2} \mathrm{O}, 0.148 \mathrm{~g}$ of $\mathrm{Na}_{2} \mathrm{SO}_{4}, 2.021 \mathrm{~g}$ of $\mathrm{CaCl}_{2} \cdot 2 \mathrm{H}_{2} \mathrm{O}, 31.841 \mathrm{~g}$ of $\mathrm{NaCl}, 1.336 \mathrm{~g}$ of KCl, $0.054 \mathrm{~g}$ of $\mathrm{NH}_{4} \mathrm{Cl}, 3.030 \mathrm{~g}$ of $\mathrm{NaHCO}_{3}$, and $0.001 \mathrm{~g}$ of $\mathrm{FeCl}_{2} \cdot 2 \mathrm{H}_{2} \mathrm{O}$. Half-strength tryptone-yeast extract-glucose (TYG) medium (HSTYG) was used to grow fermentative anaerobes (5). SRB detection kits (Labège) were used for enumerating sulfate-reducing bacteria (27). Methanogenic bacteria were grown with either sodium acetate $(10 \mathrm{mM})$, methanol (40 $\mathrm{mM})$, or $\mathrm{H}_{2}-\mathrm{CO}_{2}\left(2\right.$ bars $\left.\left[2 \times 10^{5} \mathrm{~Pa}\right]\right)$ as the substrate.

Enrichment, isolation, and growth conditions. Strain SEBR $4207^{\mathrm{T}}$ was purified by streaking the inoculum from the last positive dilution of HSTYG tube on HSTYG agar plates (2.5\% Noble agar; Difco Laboratories, Detroit, Mich.) in an anaerobic chamber (La Calhène, Vélizy, France) followed by incubation at $30^{\circ} \mathrm{C}$ under anaerobic conditions. For subsequent studies, a different medium (DP) was used. Medium DP contained (per liter) $1 \mathrm{~g}$ of $\mathrm{NH}_{4} \mathrm{Cl}, 0.3 \mathrm{~g}$ of $\mathrm{K}_{2} \mathrm{HPO}_{4}, 0.3 \mathrm{~g}$ of $\mathrm{KH}_{2} \mathrm{PO}_{4}, 3.0 \mathrm{~g}$ of $\mathrm{MgCl}_{2} \cdot 6 \mathrm{H}_{2} \mathrm{O}, 0.1 \mathrm{~g}$ of $\mathrm{CaCl}_{2} \cdot 2 \mathrm{H}_{2} \mathrm{O}, 30 \mathrm{~g}$ of $\mathrm{NaCl}, 1.0 \mathrm{~g}$ 


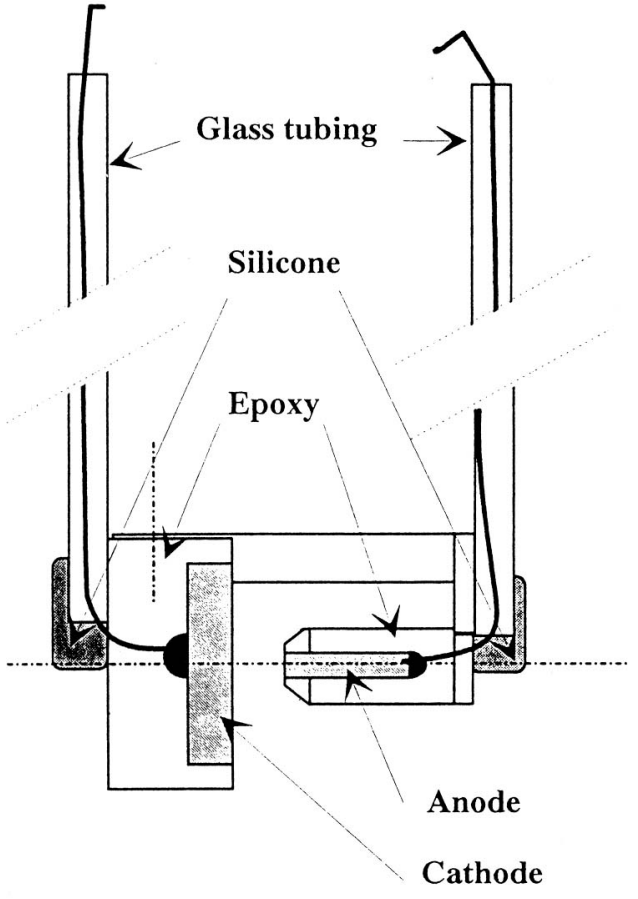

FIG. 1. Electrodes used in corrosion experiments.

of $\mathrm{KCl}, 0.5 \mathrm{~g}$ of cysteine- $\mathrm{HCl}, 0.5 \mathrm{~g}$ of $\mathrm{CH}_{3} \mathrm{COONa}, 1.0 \mathrm{~g}$ of yeast extract (Difco Laboratories), $5.0 \mathrm{~g}$ of bio-Trypticase (bioMérieux, Craponne, France), $10 \mathrm{ml}$ of a trace mineral element solution (1), and $1 \mathrm{mg}$ of resazurin. The $\mathrm{pH}$ was adjusted to 7.3 with $10 \mathrm{M} \mathrm{KOH}$. The medium was boiled under a stream of $\mathrm{O}_{2}$-free $\mathrm{N}_{2}$ gas and cooled to room temperature. Five milliliters of the medium was distributed into Hungate tubes under a stream of $\mathrm{N}_{2}-\mathrm{CO}_{2}(80: 20)$ and autoclaved for $45 \mathrm{~min}$ at $110^{\circ} \mathrm{C}$. Prior to inoculation, $0.1 \mathrm{ml}$ of $\mathrm{Na}_{2} \mathrm{~S} \cdot 9 \mathrm{H}_{2} \mathrm{O}$ (from a $2 \%$ sterile anaerobic stock solution) and $0.1 \mathrm{ml}$ of $\mathrm{Na}_{2} \mathrm{CO}_{3}$ (from a sterile $10 \%$ anaerobic stock solution) were injected into the tubes. Thiosulfate $(0.1 \mathrm{ml}$ from a sterile $1 \mathrm{M}$ anaerobic stock solution) was added to the medium when required.

Corrosion experiments. The influence of strain SEBR $4207^{\mathrm{T}}$ on the pitting corrosion of mild steel was evaluated by measuring the free-flowing current between the anode and the cathode of a simulated pit. This simulated pit consisted of a small anode kept $6 \mathrm{~mm}$ from a larger cathode (Fig. 1). The surface ratio of the electrodes was about 160 to 1 . The anode and the cathode were preconditioned to ensure their adequate functioning as previously described (6, 7). A $100-\mu \mathrm{A}$ galvanostatic current was applied between the anode and an auxiliary anode connected together (to avoid an excessive current on the anode) and the cathode. Mean current densities were $122 \mu \mathrm{A} / \mathrm{cm}^{2}$ on the anode and 20 $\mu \mathrm{A} / \mathrm{cm}^{2}$ on the cathode. The preconditioning was maintained as long as necessary for the bacterial biofilm to develop on the electrodes. Then, after the preconditioning was stopped, a zero amperemeter was used to measure the current flowing between the anode and the cathode. Once expressed in millimeters per year $(\mathrm{mm} / \mathrm{y})$, this current represents the actual penetration rate inside the pit. The medium composition, the electrochemical setup, and the sterilizing procedure have been described previously (7).

pH, temperature, and sodium chloride ranges for growth. Growth studies were performed with medium DP. For $\mathrm{pH}$ studies, prereduced media that had been dispensed into Hungate tubes were adjusted to the desired $\mathrm{pH}$ with $\mathrm{NaHCO}_{3}$ or $\mathrm{Na}_{2} \mathrm{CO}_{3}$ (added from $10 \%$ sterile anaerobic stock solutions). Growth of SEBR $4207^{\mathrm{T}}$ was tested at temperatures ranging from 20 to $45^{\circ} \mathrm{C}$. To determine the salt requirement for growth, sodium chloride was either weighed directly into tubes (for concentrations greater than $1 \%$ ) or injected from a $10 \%$ sterile stock solution (for concentrations less than 1\%) to obtain the desired concentrations.

Substrate utilization. Substrate utilization tests were performed with modified DP medium containing $20 \mathrm{mM}$ thiosulfate and bio-Trypticase at $1 \mathrm{~g} /$ liter. Substrates were injected into prereduced sterile anaerobic medium from sterile stock solutions. The substrates tested were carbohydrates at $20 \mathrm{mM}$ (arabinose, fructose, galactose, glucose, lactose, maltose, mannose, rhamnose, ribose, sucrose, sorbose, trehalose, and xylose) and fatty acids at $10 \mathrm{mM}$ (acetate, propionate, butyrate, lactate, and citrate). Amino acids were tested at $10 \mathrm{mM}$ in either the presence or the absence of thiosulfate (alanine, arginine, asparagine, glutamate, glycine, histidine, isoleucine, leucine, lysine, methionine, proline, serine, threonine, and valine)
Light and electron microscopy. Light microscopy was performed as previously described (9). Exponentially grown cells were negatively stained with $1 \%$ sodium phosphotungstic acid $(\mathrm{pH} 7.2)$. For preparation of thin sections, exponentially grown cells were centrifuged and fixed for $1 \mathrm{~h} \mathrm{in} 3 \%$ (wt/vol) glutaraldehyde prepared in $\mathrm{HCl}-\mathrm{cacodylate}$ buffer $(\mathrm{pH} 6.0)$ containing $0.7 \mathrm{M}$ sucrose and fixed again overnight in $1 \%(\mathrm{wt} / \mathrm{vol})$ osmium tetroxide prepared in $0.75 \mathrm{M}$ sucrose. The cells were then washed and embedded in $2 \%$ agarose and stained with $4 \%$ uranyl acetate. The agar was cut into small cubes, dehydrated in acetone, and embedded in Araldite. Thin sections were stained with 5\% uranyl acetate for 20 min and with $2 \%$ lead citrate for $10 \mathrm{~min}$. Electron microphotographs were taken with a Hitachi model $\mathrm{H} 600$ electron microscope at an accelerating voltage of 75 $\mathrm{kV}$.

Cytochrome analysis. Cell extracts were examined for the presence of cytochrome and desulfoviridin as already reported (33).

Analytical techniques. Unless otherwise indicated, experiments were conducted in duplicate. Growth was measured at $580 \mathrm{~nm}$ by inserting tubes directly into a Shimadzu (Kyoto, Japan) UV-160A spectrophotometer. Sulfide was determined photometrically as collodial CuS according to the method of CordRuwisch (12). $\mathrm{H}_{2}$ and fermentation products (alcohols and fatty acids) were measured as described previously (17).

Determination of $\mathbf{G}+\mathbf{C}$ content. DNA was extracted and purified by chromatography on hydroxyapatite. The guanine-plus-cytosine $(\mathrm{G}+\mathrm{C})$ content was determined by high-performance liquid chromatography by the method of Mesbah et al. (31). Nonmethylated lambda DNA (Sigma) was used as a standard (8).

$16 \mathrm{~S}$ rRNA sequence studies. Amplification of the 16S rRNA from semipurified DNA followed by purification of the amplified product was performed as described previously $(26,38)$. The sequence was determined with an ABI automated DNA sequencer by using a Prism dideoxy terminator cycle sequencing kit and the protocols recommended by the manufacturer (Applied Biosystems Inc.) The 12 primers used for sequencing have been described previously (38). The $16 \mathrm{~S}$ ribosomal DNA sequence was manually aligned with reference sequences of various members of the domain Bacteria by using the alignment editor ae2. Reference sequences were obtained from the Ribosomal Database Project $(25$ 30). A phylogenetic analysis was performed with various programs implemented as part of the PHYLIP package (19) as described below. The pairwise evolutionary distances based on 1,245 unambiguous bases were determined by the method of Jukes and Cantor (23), and dendrograms were constructed from evolutionary distances by the neighbor-joining method. A transversion analysis was performed with the program DNAPARS. Tree topology determined with 100 data sets was examined by running a script file consisting of the following programs: SEOBOOT, DNADIST, FITCH, and CONSENSE. Programs available in the Molecular Evolutionary Genetic Analysis (MEGA) package, version 1 (24), were also used in the analysis. All of the programs except MEGA were run on a Sun Sparc workstation. Mega was run on a Compaq Contura $410 \mathrm{CX}$ IBM-compatible notebook computer.

Nucleotide sequence accession number. The nucleotide sequence of the $16 \mathrm{~S}$ rRNA of strain SEBR $4207^{\mathrm{T}}$ has been deposited in the GenBank database under accession no. U52817.

\section{RESULTS}

Bacterial counts in BB325 wellhead sample. At the time of our investigation, the new oil pipeline was treated by frequent biocide injections at elevated concentration. Since this treatment drastically reduced the bacterial numbers within the line, we collected water samples upstream of the corroded pipe and from the non-biocide-treated producing wellheads whose tubings were actively corroded.

The bacterial community (Table 1) was exclusively composed of strict anaerobes. The MPN counts showed that most bacterial cells enumerated under the epifluorescence microscope were cultivable. Fermentative bacteria outnumbered

TABLE 1. Bacterial counts in well BB325 water sample

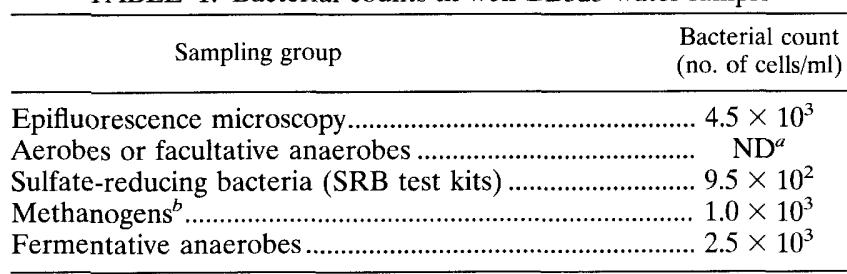

\footnotetext{
$a \mathrm{ND}$, not detected.
${ }^{b}$ Methanogens comprise hydrogenotrophs $\left(0.5 \times 10^{3} / \mathrm{ml}\right)$ and methylotrophs $\left(0.5 \times 10^{3} / \mathrm{ml}\right)$.
} 


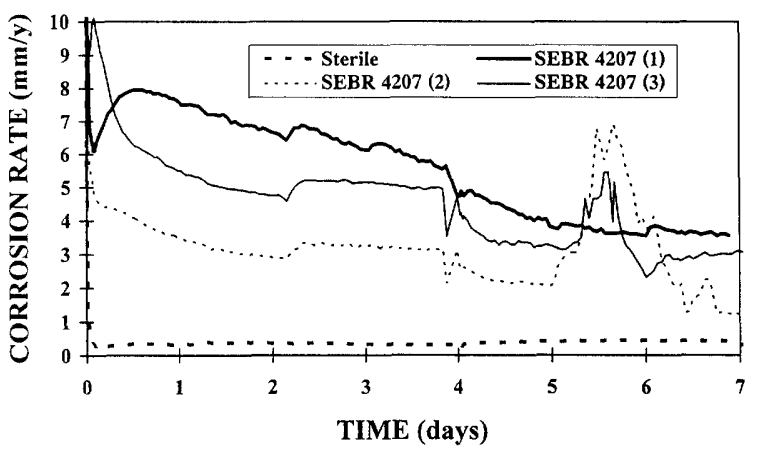

FIG. 2. Corrosion rates induced by strain SEBR $4207^{\mathrm{T}}$ in three replicated experiments (experiment numbers given in parentheses).

both sulfate-reducing and methanogenic bacteria. Seven different fermentative strains were purified, and six of them were shown to reduce sodium thiosulfate to hydrogen sulfide (28), including the recently described novel species Haloanaerobium congolense (37). Two SRB strains (42) and two methanogens, including the new species Methanoplanus petrolearius (34), were also isolated. None of these isolates displayed characteristics common to the described species $(34,37,42)$.

Enrichment and isolation. Strain SEBR $4207^{\mathrm{T}}$ was purified from the last positive MPN HSTYG tube by three consecutive streakings on HSTYG agar plates, followed by incubation at $30^{\circ} \mathrm{C}$ in an anaerobic chamber. After 7 days of incubation, colonies $2 \mathrm{~mm}$ in diameter developed. The colonies were white and round with smooth edges. A single colony (designated as strain SEBR $4207^{\mathrm{T}}$ ) was picked and transferred into HSTYG liquid medium.

Corroding activity of strain SEBR $4207^{\mathrm{T}}$. Figure 2 shows the pit penetration rates (in millimeters per year) versus time after the preconditioning for one experimental cell kept sterile and three independent experimental cells inoculated with strain SEBR $4207^{\mathrm{T}}$. Under sterile conditions, the penetration rate decreased to a fraction of millimeters per year within a few hours of coupling, after the preconditioning current was stopped. In the presence of strain SEBR $4207^{\mathrm{T}}$, a stable galvanic current of 130 to $350 \mu \mathrm{A} / \mathrm{cm}^{2}$ was measured. When expressed as a penetration rate, this corresponded to 325 to $865 \mathrm{mg}$ of iron per $\mathrm{dm}^{2}$ per day, or 1.5 to $4.0 \mathrm{~mm} / \mathrm{y}$ (Fig. 2). These differences were suspected to result from differences in biofilm formation. These values are far above the accepted industrial limit of $0.1 \mathrm{~mm} / \mathrm{y}$ for mild steel corrosion.

Morphology. Strain SEBR $4207^{\mathrm{T}}$ was a vibrio measuring 3 to $5 \mu \mathrm{m}$ by $1 \mu \mathrm{m}$ (Fig. 3). Electron microscopy of negatively stained cells indicated the presence of from one up to five lateral flagella (Fig. 4). Electron microscopy of thin sections of cells of strain SEBR $4207^{\mathrm{T}}$ exhibited a multilayered cell wall ultrastructure with an outer membrane typical of gram-negative bacteria (Fig. 5).

Growth characteristics. Strain SEBR $4207^{\mathrm{T}}$ grew from 20 to $45^{\circ} \mathrm{C}$, with an optimum temperature for growth at $42^{\circ} \mathrm{C}$. No growth was observed at $50^{\circ} \mathrm{C}$ (Fig. 6a). It required $\mathrm{NaCl}$ for growth, with an optimum of $3 \% \mathrm{NaCl}$. No growth occurred at $11 \% \mathrm{NaCl}$ (Fig. 6b). The optimum $\mathrm{pH}$ for growth was 7.0, with no growth at pH 5.5 and 8.8 .

Substrate utilization and physiological characteristics. Strain SEBR $4207^{\mathrm{T}}$ utilized peptides in the form of bio-Trypticase and Bacto Peptone and amino acids in the form of Casamino Acids as its sole carbon and energy sources. Proteins such as gelatin or casein, carbohydrates (arabinose, fructose, galactose, glucose, lactose, maltose, mannose, rhamnose, ri- bose, sucrose, sorbose, trehalose, and xylose), and fatty acids (acetate, butyrate, propionate, citrate, and lactate) were not utilized. End products formed from peptide utilization included acetate, isobutyrate, isovalerate, 2-methylbutyrate, $\mathrm{CO}_{2}$, and $\mathrm{H}_{2}$. Serine and histidine were fermented, whereas arginine, glutamate, leucine, isoleucine, alanine, valine, methionine, and asparagine were only oxidized in the presence of thiosulfate as an electron acceptor. Lysine, proline, threonine, and glycine were not used in either the presence or the absence of thiosulfate. Serine was fermented to acetate. In the presence of thiosulfate, alanine was oxidized to acetate, leucine to 3-methylbutyrate, isoleucine to 2-methylbutyrate, valine to isobutyrate, asparagine to acetate, and methionine to propionate. Although yeast extract was not required for utilization of peptides and Casamino Acids, its presence improved growth. In contrast, yeast extract was required for the use of any single amino acid as an energy source. Strain SEBR $4207^{\mathrm{T}}$ used elemental sulfur and thiosulfate, but not sulfate, as electron acceptors with peptides. Strain SEBR $4207^{\mathrm{T}}$ did not perform thiosulfate or elemental sulfur disproportionation in the presence of acetate or yeast extract as a carbon source. Moreover, growth did not occur on $\mathrm{H}_{2}$ plus thiosulfate and acetate as the carbon source. The presence of either elemental sulfur or thiosulfate increased the biomass and the growth rate (Fig. 7). In addition, $\mathrm{H}_{2} \mathrm{~S}$ was produced with a concomitant decrease in $\mathrm{H}_{2}$ when thiosulfate or sulfur was present. $\mathrm{H}_{2}$ inhibited the growth of strain SEBR $4207^{\mathrm{T}}$, but this inhibition could be partially reversed by the addition of thiosulfate and sulfur. Overall, the presence of thiosulfate had a much greater effect on growth than sulfur did. Strain SEBR $4207^{\mathrm{T}}$ was unable to use carbohydrates and volatile fatty acids as carbon and energy sources with yeast extract and/or thiosulfate. The cells did not contain cytochrome or desulfoviridin.

$\mathbf{G}+\mathbf{C}$ content. The $\mathrm{G}+\mathrm{C}$ content of isolate SEBR $4207^{\mathrm{T}}$ was $56 \mathrm{~mol} \%$.

16S rRNA sequence analysis. Using 12 primers, we determined 1,505 nucleotide bases from positions 8 to 1542 (Escherichia coli numbering of Winker and Woese [44] of the $16 \mathrm{~S}$ rRNA gene of strain SEBR $4207^{\mathrm{T}}$ ). A phylogenetic analysis performed with representatives of the domain Bacteria revealed that strain SEBR $4207^{\mathrm{T}}$ was a member of the subdivision containing gram-positive bacteria with DNA $\mathrm{G}+\mathrm{C}$ content less than $55 \mathrm{~mol} \%$ and clustered with members of the clostridial group. A recent phylogenetic analysis of the $16 \mathrm{~S}$

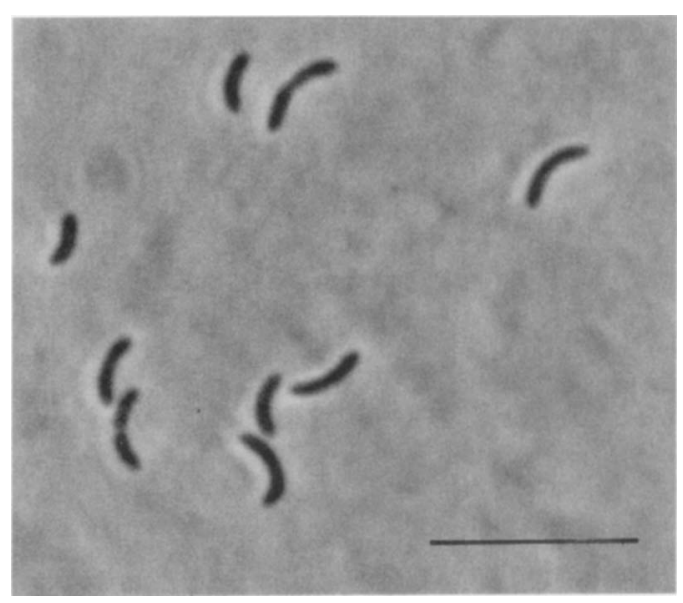

FIG. 3. Phase-contrast photomicrograph of strain SEBR $4207^{\mathrm{T}}$ showing vibrioid cells. Bar, $10 \mu \mathrm{m}$. 


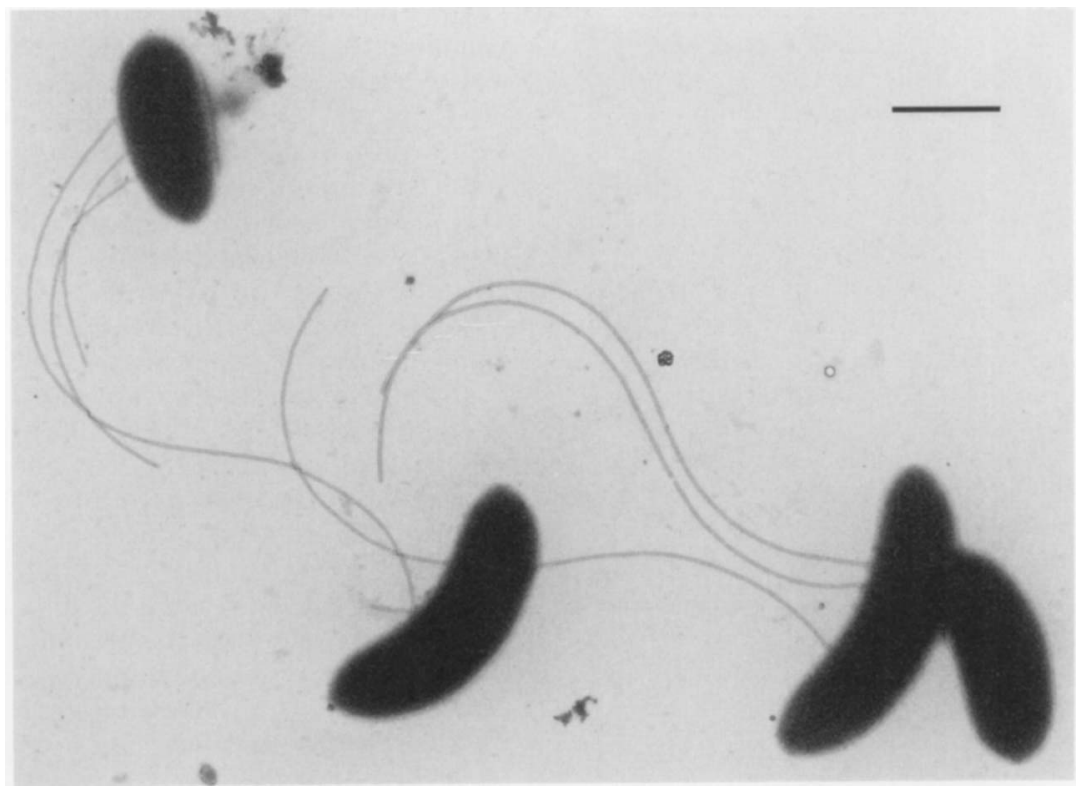

FIG. 4. Electron micrograph of negative-stained culture of strain SEBR $4207^{\mathrm{T}}$ showing lateral flagellation. Bar, $1 \mu \mathrm{m}$.

rRNAs of the members of the clostridial group revealed that there are at least 19 defined clusters and several lines of descent. This led to the creation of five new genera and 11 new species combinations to accommodate phylogenetically distinct organisms (11). Phylogenetic analysis revealed that strain SEBR $4207^{\mathrm{T}}$ was peripherally related to cluster $\mathrm{V}$, consisting of the family Thermoanaerobacteriaceae, with a similarity value of $83 \%$. A bootstrap value of 53 was obtained from a 100 data sets, indicating a poor relationship between strain SEBR $4207^{\mathrm{T}}$ and cluster V. Several data sets, which included different representatives from the various clusters of the subdivision containing gram-positive bacteria with DNA G+C content less than $55 \mathrm{~mol} \%$, consistently placed strain SEBR $4207^{\mathrm{T}}$ as a member of a novel line of descent at the periphery of cluster $\mathrm{V}$ and the genus Dictyoglomus (39). Transversion analysis did not affect the position of strain SEBR $4207^{\mathrm{T}}$ in the phylogenetic tree. The evolutionary distances separating strain SEBR $4207^{\mathrm{T}}$ and its relative and the dendrogram derived from these distances are depicted in Table 2 and Fig. 8, respectively. The $\mathrm{G}+\mathrm{C}$ content of the $16 \mathrm{~S}$ rRNA gene was $56 \mathrm{~mol} \%$.

\section{DISCUSSION}

The bacterial flora of oil field production water transported in an actively corroded undersea oil pipeline was shown to be composed of only strict anaerobes, which appear to commonly dominate such ecosystems $(2,20)$. Most of the bacteria that compose this consortium were cultivated (Table 1), although it is generally considered that very few bacteria from the natural environment are cultivable under laboratory conditions. Similar observations were recently reported from another oil field facility (32). Fermentative, thiosulfate-reducing anaerobic bacteria exhibited significant populations in the oil field studied (Table 1), a situation which seems to be common in oil field reservoirs $(14,20,36)$.

Thiosulfate is produced from chemical oxidation of sulfide $(10,15,22)$. It is common in aquatic environments and has also recently been detected in oil fields. It has been hypothesized from models $(13,16)$ and field observations $(14,28)$ that its presence in oil fields may increase the risk of biocorrosion of oil pipelines. We have therefore initiated studies of the isola-

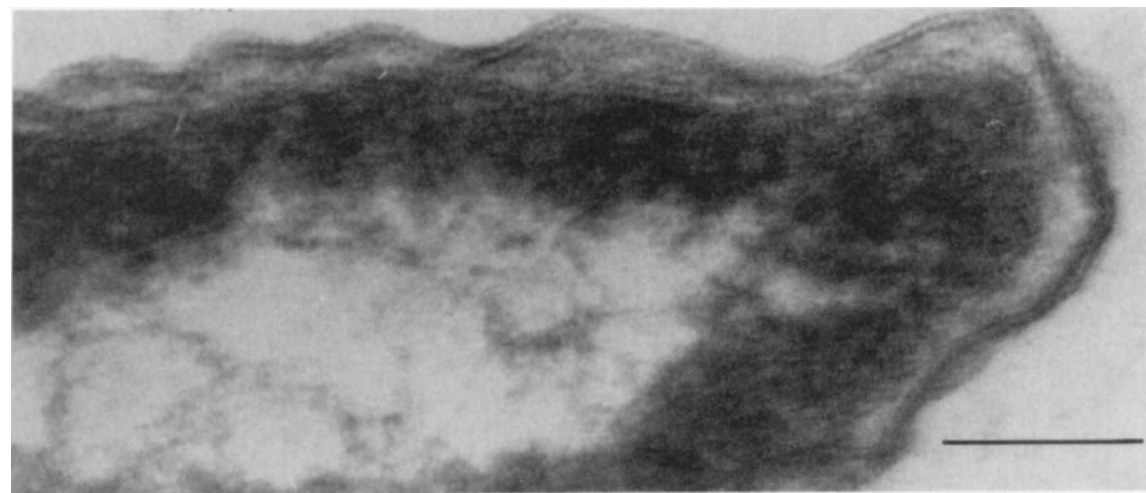

FIG. 5. Thin sections of strain SEBR $4207^{\mathrm{T}}$ showing a typical multilayered gram-negative cell wall structure with an outer membrane. Bar, $0.1 \mu \mathrm{m}$. 

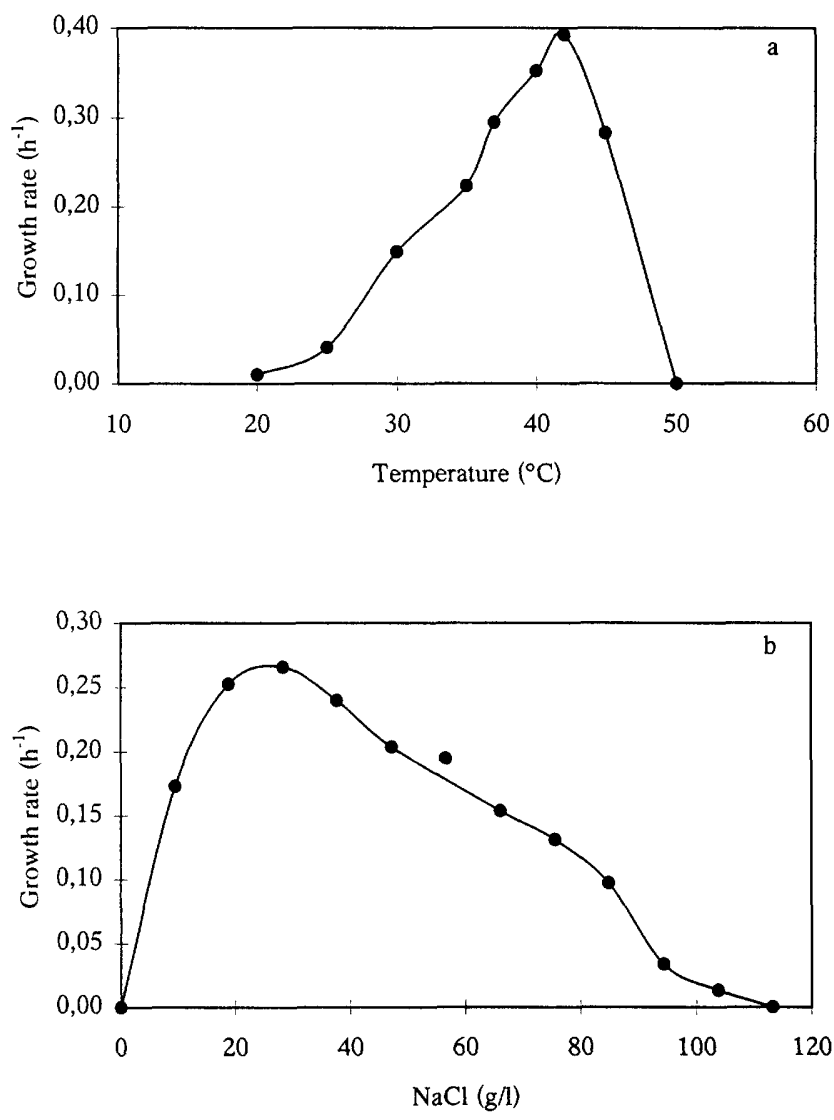

FIG. 6. (a) Effect of temperature on the growth of strain SEBR $4207^{\mathrm{T}}$ cultured in medium DP and incubated at various temperatures. (b) Effect of $\mathrm{NaCl}$ concentration on the growth of strain SEBR $4207^{\mathrm{T}}$ cultured in medium DP containing sodium chloride concentrations ranging from 0 to $115 \mathrm{~g} /$ /iter and incubated at $42^{\circ} \mathrm{C}$.

tion of anaerobic thiosulfate-reducing bacteria from oil field environments undergoing active corrosion. Strain SEBR $4207^{\mathrm{T}}$ was isolated from an African oil field in Congo and was observed to use thiosulfate, but not sulfate, as an electron acceptor. One important characteristic of this strain, when tested in appropriate in vitro experiments, was that it induced corrosion rates into mild steel at least 1 order of magnitude higher than the industrial design limit. This corroding activity was similar to or higher than that recorded for sulfate-reducing bacteria in similar experiments (6). This paper thus shows for the first time that thiosulfate-, non-sulfate-reducing bacteria, as previously suspected, do have a significant corrosive activity.

Strain SEBR $4207^{\mathrm{T}}$ also used elemental sulfur as an electron acceptor. The reduction of elemental sulfur to sulfide is not an obligate physiological trait for strain SEBR $4207^{\mathrm{T}}$, and therefore it is different from the mesophilic sulfur-respiring bacteria, viz. Desulfuromonas acetoxidans, Desulfurella acetivorans, and Desulfovibrio sp. (35), or the thermophilic members of domains Archaea and Bacteria $(3,40,41)$. The metabolism of this isolate is unique among the mesophilic sulfur reducers because it resembles to some degree that of the hyperthermophilic members of the domain Archaea when proteinaceous compounds are used in the presence of elemental sulfur as an electron acceptor (4). Strain SEBR $4207^{\mathrm{T}}$ possesses unique phenotypic characteristics, because it utilizes only a limited range of substrates, which include amino acids and peptides, but not proteins such as gelatin and casein, carbohydrates, or volatile fatty acids.

The isolation of strain SEBR $4207^{\mathrm{T}}$ extends the known diversity of microorganisms involved in amino acid and peptide degradation and emphasizes the importance of thiosulfate or sulfur reducers in the oxidation of peptides and amino acids. Thiosulfate dramatically improves the utilization of amino acids and peptides by members of the genus Thermoanaerobacter (18) in a manner similar to that of strain SEBR $4207^{\mathrm{T}}$. Interestingly, Thermoanaerobacter species are the nearest phylogenetic relatives of strain SEBR $4207^{\mathrm{T}}$, although the distance separating them is very large ( $83 \%$ similarity). In addition, strain SEBR $4207^{\mathrm{T}}$ is a mesophile, utilizes a very limited range of substrates, and has $\mathrm{G}+\mathrm{C}$ content of $56 \mathrm{~mol} \%$, traits which clearly differentiate strain SEBR $4207^{\mathrm{T}}$ from members of all known bacteria, including members of the genus Thermoanaerobacter.

Strain SEBR $4207^{\mathrm{T}}$ stains gram-negative and has a gramnegative cell wall ultrastructure, but is phylogenetically related to members of the subdivision containing gram-positive subdivision bacteria with DNA G+C content of less than $55 \%$. This discrepancy between phenotype and genotype is not new in this subdivision. For example, the closest relatives of strain SEBR $4207^{\mathrm{T}}$ are the members of the genus Thermoanaerobacter. All members of this genus are gram-positive, except Thermoanaerobacter ethanolicus, which possesses a gram-negative cell wall (43). Members of Dictyoglomus, which are also distant phylogenetic relatives of strain SEBR $4207^{\mathrm{T}}$ and Thermoanaerobacter species, possess gram-negative cell wall (39). Interestingly, the common phenotypic element binding strain SEBR $4207^{\mathrm{T}}$ with Thermoanaerobacter and Dictyoglomus is their obligate anaerobic nature.

Strain SEBR $4207^{\mathrm{T}}$ is an anaerobic, slightly halophilic vibrio but does not utilize sulfate as an electron acceptor, and despite its morphology and ability to utilize thiosulfate, it cannot be described as a member of the sulfate-reducing bacteria. Strain SEBR $4207^{\mathrm{T}}$ is also phylogenetically distinct from all sulfatereducing bacteria and members of the family Thermoanaerobacteriaceae. Because strain SEBR $4207^{\mathrm{T}}$ cannot be assigned to any known bacterial genera, we propose that it be designated a member of a new genus, Dethiosulfovibrio peptidovorans, gen. nov., sp. nov.

Description of Dethiosulfovibrio gen. nov. Dethiosulfovibrio (De.thi.o.sul.fo.vi'bri.o. L. pref. de, from; Gr. n. thios, sulfur; L. n. sulfur, sulfur; thiosulfo, thiosulfate; L. v. vibrio, to vibrate;

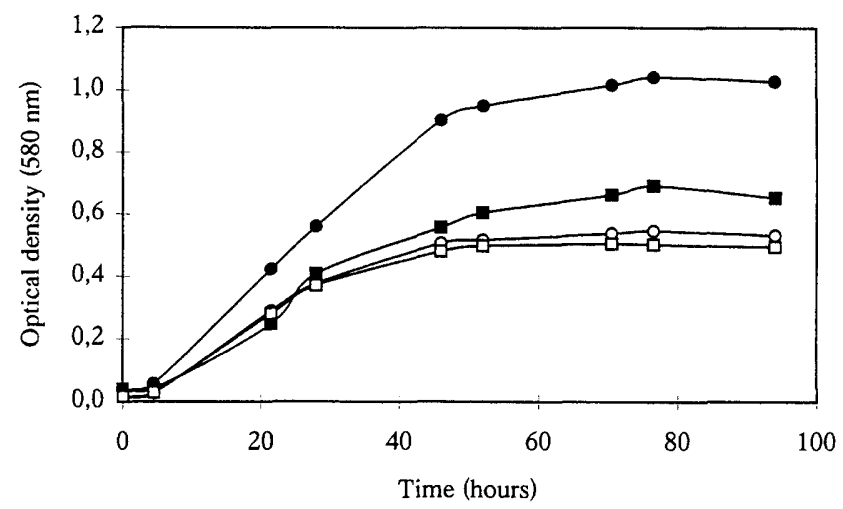

FIG. 7. Effect of different electron acceptors on the growth of strain SEBR $4207^{\mathrm{T}}$ cultured on medium DP. $\mathbf{\square}$, elemental sulfur, $2 \% ; \boldsymbol{9}$, thiosulfate, $20 \mathrm{mM}$; $\square$, sulfate, $20 \mathrm{mM}$. Medium DP without any electron acceptors added acted as a control $(\mathrm{O})$ 
TABLE 2. Evolutionary distance matrix determined from a comparison of the $16 \mathrm{~S}$ rRNA sequence of strain SEBR $4207^{\mathrm{T}}$ and related genera by the method of Jukes and Cantor $(23)^{a}$

\begin{tabular}{|c|c|c|c|c|c|c|c|c|c|c|c|c|c|c|c|}
\hline \multirow{2}{*}{ Organism } & \multicolumn{15}{|c|}{ Evolutionary distance of sequence from that of organism: } \\
\hline & 1 & 2 & 3 & 4 & 5 & 6 & 7 & 8 & 9 & 10 & 11 & 12 & 13 & 14 & 15 \\
\hline Strain SEBR 4207 & & & & & & & & & & & & & & & \\
\hline Thermoanaerobacter thermocopriae & 83.0 & & & & & & & & & & & & & & \\
\hline Thermoanaerobacter acetoethylicus & 82.7 & 94.2 & & & & & & & & & & & & & \\
\hline Thermoanaerobacter ethanolicus & 83.4 & 94.8 & 97.0 & & & & & & & & & & & & \\
\hline Thermoanaerobacter kivui & 83.8 & 94.2 & 96.1 & 97.1 & & & & & & & & & & & \\
\hline Dictyoglomus thermophilum & 80.3 & 85.5 & 85.1 & 85.8 & 85.1 & & & & & & & & & & \\
\hline Desulfotomaculum thermobenzoicum & 81.8 & 86.8 & 87.1 & 88.2 & 87.9 & 82.5 & & & & & & & & & \\
\hline 8 Desulfotomaculum thermosapovorans & 81.3 & 85.2 & 85.4 & 86.1 & 85.7 & 81.0 & 89.4 & & & & & & & & \\
\hline 9 Desulfotomaculum australicum & 81.3 & 86.3 & 86.4 & 87.6 & 87.6 & 82.9 & 94.6 & 89.3 & & & & & & & \\
\hline 10 Thermoanaerobacterium thermosaccharolyticum & 80.2 & 86.3 & 87.1 & 87.6 & 87.4 & 81.5 & 86.0 & 84.3 & 85.4 & & & & & & \\
\hline 11 Thermoanaerobacterium thermosulfurigenes & 79.8 & 86.0 & 87.4 & 87.4 & 87.3 & 81.8 & 86.3 & 84.5 & 85.4 & 98.1 & & & & & \\
\hline 12 Moorella thermoacetica & 81.6 & 87.9 & 88.2 & 89.1 & 88.8 & 83.5 & 89.4 & 88.6 & 88.8 & 86.9 & 87.1 & & & & \\
\hline 13 Syntrophomonas bryantii & 80.1 & 84.9 & 85.3 & 85.9 & 85.4 & 81.6 & 85.6 & 84.1 & 85.7 & 84.2 & 84.5 & 86.9 & & & \\
\hline 14 Syntrophomonas wolfei & 80.2 & 85.3 & 85.6 & 86.1 & 85.8 & 81.9 & 85.3 & 84.4 & 86.2 & 83.8 & 83.9 & 86.9 & 94.4 & & \\
\hline 15 Selenomonas ruminantium & 79.5 & 82.1 & 82.5 & 83.7 & 82.5 & 79.9 & 83.6 & 85.2 & 83.0 & 82.7 & 82.8 & 83.1 & 83.5 & 83.1 & \\
\hline 16 Megasphaera elsdenii & 80.2 & 81.0 & 81.7 & 82.9 & 82.7 & 79.4 & 81.9 & 83.0 & 81.9 & 82.7 & 82.3 & 83.8 & 81.0 & 81.3 & 87.9 \\
\hline
\end{tabular}

${ }^{a}$ See Materials and Methods for details. The sequences used in the analysis were obtained from the Ribosomal Database Project, version 5 (25), and from EMBL for Desulfotomaculum thermosapovorans (accession no. Z26315). Only 1,245 unambiguous nucleotide positions were used in the analysis.

M.L. masc. n. vibrio that vibrates, a generic name; M.L. masc. n. Dethiosulfovibrio, a vibrio that reduces thiosulfate). Cells are gram-negative vibrios, mesophilic, neutrophilic, and slightly halophilic strict anaerobes that use peptides and amino acids, but not sugars, as the sole carbon and energy sources. The organism uses elemental sulfur and thiosulfate, but not sulfate, as electron acceptors. Growth is inhibited by hydrogen. Cells do not contain cytochrome or desulfoviridin.

Description of Dethiosulfovibrio peptidovorans gen. nov., sp. nov. Dethiosulfovibrio peptidovorans (pep.ti.do.vo' rans. Gr. adj. peptos, cooked; L. v. voro, to devour; M.L. part adj. peptidovorans, devouring peptides). Cells are gram-negative vibrios, 3 to $5 \mu \mathrm{m}$ by $1 \mu \mathrm{m}$. Growth occurs at temperatures between 20 and $45^{\circ} \mathrm{C}$ (optimum $42^{\circ} \mathrm{C}$ ) and at $\mathrm{pH}$ values between 5.5 and 8.8 (optimum 7.0). The organism is slightly halophilic; growth requires $\mathrm{NaCl}$ (optimum, $3 \%$ ), but no growth occurs at $11 \%$ $\mathrm{NaCl}$. The organism is a strictly anaerobic bacterium using peptides and amino acids as its sole carbon and energy sources.

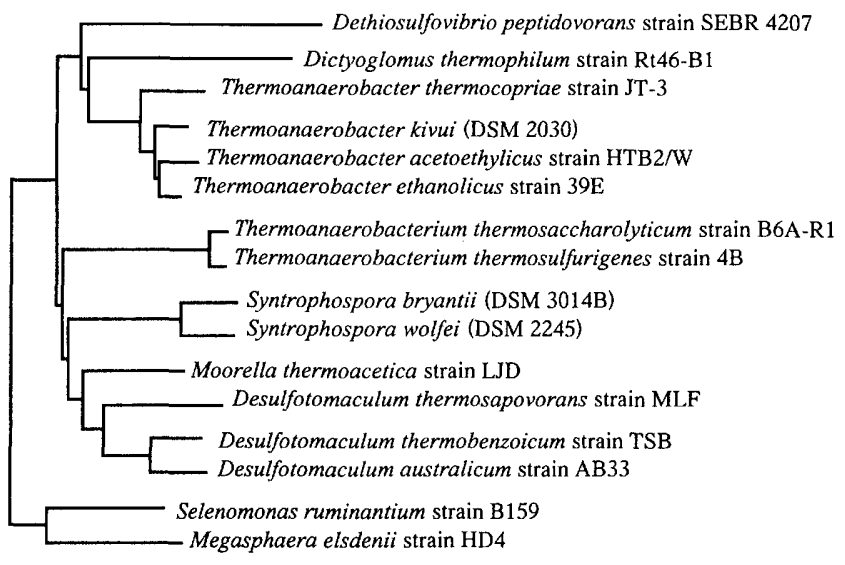

0.10

FIG. 8. Phylogenetic position of strain SEBR $4207^{\mathrm{T}}$ among members of the subdivision containing gram-positive bacteria with DNA G+C content of less than 55 mol\%.
The organism ferments serine and histidine. D. peptidovorans uses alanine, arginine, asparagine, glutamate, isoleucine, leucine, methionine, and valine only in the presence of thiosulfate as an electron acceptor. The organism produces acetate, isobutyrate, isovalerate, 2-methylbutyrate, $\mathrm{CO}_{2}$, and $\mathrm{H}_{2}$ from peptides. Yeast extract is not required, but improves growth on Casamino Acids and peptides. Yeast extract is required for the use of a single amino acid. The organism uses elemental sulfur and thiosulfate, but not sulfate, as electron acceptors with peptides. The organism does not perform disproportionation of thiosulfate or elemental sulfur. The presence of either sulfur or thiosulfate increases the biomass and the growth rate. In addition, $\mathrm{H}_{2} \mathrm{~S}$ is produced with a concomitant decrease in $\mathrm{H}_{2}$ when thiosulfate or sulfur is present. Growth is inhibited by hydrogen, but this inhibition is partially reversed by the addition of thiosulfate. Cells do not contain cytochrome or desulfoviridin. The organism is unable to utilize proteins (gelatin and casein), carbohydrates (arabinose, fructose, galactose, glucose, lactose, maltose, mannose, rhamnose, ribose, sucrose, sorbose, trehalose, and xylose), fatty acids (acetate, propionate, butyrate, citrate, and lactate) as its sole carbon and energy source with added yeast extract, bio-Trypticase, and/or thiosulfate.

The DNA base composition ( $\mathrm{G}+\mathrm{C}$ content) is $56 \mathrm{~mol} \%$. D. peptidovorans lives in an oil-producing well in Africa. The type strain is SEBR 4207 (=DSM 11002).

\section{ACKNOWLEDGMENTS}

We thank C. E. Hatchikian for helpful discussions, O. Arnauld and C. Lanau for technical assistance, and P. A. Roger for critical comments on the manuscript.

This work was supported by grants from Elf Aquitaine (G.R. and X.C.) and in part from the Australian Research Council (B.K.C.P.).

\section{REFERENCES}

1. Balch, W. E., G. E. Fox, L. J. Magrum, C. R. Woese, and R. S. Wolfe. 1979 Methanogens: reevaluation of a unique biological group. Microbiol. Rev. 43:260-296.

2. Bernard, F. P., J. Connan, and M. Magot. 1992. Indigenous microorganisms in connate water of many oil fields: a new tool in exploration and production techniques, paper SPE 24811, p. 467-476. In Proceedings of the 67th Annual Technical Conference and Exhibition of the Society of Petroleum Engineers. Society of Petroleum Engineers Inc., Richardson, Tex.

3. Bonch-Osmolovskaya, E. A. 1994. Bacterial sulfur reduction in hot vents. FEMS Microbiol. Rev. 15:65-77. 
4. Bonch-Osmolovskaya, E. A., and K. O. Stetter. 1991. Interspecies hydrogen transfer in cocultures of thermophilic Archaea. Syst. Appl. Microbiol. 14: 205-208.

5. Brefort, G., M. Magot, H. Ionesco, and M. Sebald. 1977. Characterization and transferability of Clostridium perfringens plasmids. Plasmid 1:52-66.

6. Campaignolle, X., J. S. Luo, J. Bullen, D. C. White, J. Guezennec, and J.-L. Crolet. 1993. Stabilization of localized corrosion of carbon steel by sulfatereducing bacteria, paper 93302. In Corrosion 93. National Association of Corrosion Engineers, Houston, Tex.

7. Campaignolle, X., P. Caumette, F. Dabosi, and J.-L. Crolet. 1996. The role of thiosulfate in the microbially induced pitting of carbon steel, paper 96273 . In Corrosion 96. National Association of Corrosion Engineers, Houston, Tex.

8. Cashion, P., M. A. Holder-Franklin, J. McCully, and M. Franklin. 1977. A rapid method for the base ratio determination of bacterial DNA. Anal. Biochem. 81:461-466.

9. Cayol, J.-L., B. Ollivier, B. K. C. Patel, G. Prensier, J. Guezennec, and J.-L. Garcia. 1994. Isolation and characterization of Halothermothrix orenii gen. nov., sp. nov., a halophilic, thermophilic, fermentative, strictly anaerobic bacterium. Int. J. Syst. Bacteriol. 44:534-540.

10. Cline, J. D., and F. A. Richards. 1969. Oxygenation of hydrogen sulfide in seawater at constant salinity, temperature, and pH. Environ. Sci. Technol. 3:838-843.

11. Collins, M. D., P. A. Lawson, A. Willems, J. J. Cordoba, J. FernandezGarayzabal, P. Garcia, J. Cai, H. Hippe, and J. A. E. Farrow. 1994. The phylogeny of the genus Clostridium: proposal of five new genera and eleven new species combinations. Int. J. Syst. Bacteriol. 44:812-826.

12. Cord-Ruwisch, R. 1985. A quick method for the determination of dissolved and precipitated sulfides in cultures of sulfate-reducing bacteria. J. Microbiol. Methods 4:33-36.

13. Crolet, J.-L., S. Daumas, and M. Magot. 1993. pH regulation by sulfatereducing bacteria, paper 303. In Corrosion 93. National Association of Corrosion Engineers, Houston, Tex.

14. Crolet, J.-L., and M. Magot. 1996. Non SRB sulfidogenic bacteria from oil field production facilities. Mater. Performance March:60-64.

15. Cypionka, H., F. Widdel, and N. Pfennig. 1985. Survival of sulfate-reducing bacteria after oxygen stress, and growth in sulfate-free oxygen-sulfide gradients. FEMS Microbiol. Lett. 31:39-45.

16. Daumas, S., M. Magot, and J.-L. Crolet. 1993. Measurement of the net production of acidity by a sulphate-reducing bacterium: experimental checking of theoretical models of microbially influenced corrosion. Res. Microbiol 144:327-332.

17. Fardeau, M.-L., J.-L. Cayol, M. Magot, and B. Ollivier. 1993. $\mathrm{H}_{2}$ oxidation in the presence of thiosulfate, by a Thermoanaerobacter strain isolated from an oil-producing well. FEMS Microbiol. Lett. 113:327-332.

18. Faudon, C., M.-L. Fardeau, J. Heim, B. K. C. Patel, M. Magot, and B. Ollivier. 1995. Peptide and amino acid oxidation in the presence of thiosulfate by members of the genus Thermoanaerobacter. Curr. Microbiol. 31:152157.

19. Felsenstein, J. 1993. PHYLIP (Phylogenetic Inference Package), version 3.51c. Department of Genetics, University of Washington, Seattle.

20. Grassia, G. S., K. M. McLean, P. Glénat, J. Bauld, and A. J. Sheehy. 1996 A systematic survey for thermophilic fermentative bacteria and archaea in high temperature petroleum reservoirs. FEMS Microbiol. Ecol. 21:47-58.

21. Hobbie, J. E., R. J. Daley, and S. Jasper. 1977. Use of Nuclepore filters for counting bacteria by fluorescence microscopy. Appl. Environ. Microbiol. 33:1225-1228.

22. Jørgensen, B. B. 1990 . A thiosulfate shunt in the sulfur cycle of marine sediments. Science 249:152-154.

23. Jukes, T. H., and C. R. Cantor. 1969. Evolution of protein molecules, p 21-132. In H. N. Munro (ed.), Mammalian protein metabolism. Academic Press, New York, N.Y.

24. Kumar, S., K. Tamura, and M. Nei. 1993. MEGA: Molecular Evolutionary Genetic Analysis, version 1.0. The Pennsylvania State University, University Park.

25. Larsen, N., G. J. Olsen, B. L. Maidak, M. J. McCaughey, R. Overbeek, T. J. Macke, T. L. Marsh, and C. R. Woese. 1993 . The ribosomal database project.
Nucleic Acids Res. 21(Suppl.):3021-3023.

26. Love, C. A., B. K. C. Patel, P. D. Nichols, and E. Stackebrandt. 1993 Desulfotomaculum australicum, sp. nov., a thermophilic sulfate-reducing bacterium isolated from the Great Artesian Basin of Australia. Syst. Appl. Microbiol. 16:244-251.

27. Magot, M., L. Mondeil, J. Ausseur, and J. Seureau. 1988. Detection of sulfate-reducing bacteria, p. 37-52. In C. C. Gaylarde and J. G. Morton (ed.), Biocorrosion, proceedings of a joint meeting between the Biodeterioration Society and the French Corrosion Group. Biodeterioration Society, London, United Kingdom.

28. Magot, M., L. Carreau, J.-L. Cayol, B. Ollivier, and J.-L. Crolet. 1995. Sulphide-producing, not sulphate-reducing anaerobic bacteria presumptively involved in bacterial corrosion, p. 293-300. In C. A. C. Sequeira (ed.) Proceedings of the 3rd European Federation of Corrosion Workshop on Microbial Corrosion, Portugal. The Institute of Materials, London, United Kingdom.

29. Magot, M., G. Ravot, B. Ollivier, B. K. C. Patel, and J.-L. Garcia. 1996 Dethiosulfovibrio peptidovorans, gen. nov., sp. nov., a new anaerobic halophilic thiosulfate-reducing bacterium isolated from an oil field, abstr. R-24 p. 473. In Abstracts of the 96th General Meeting of the American Society for Microbiology 1996. American Society for Microbiology, Washington, D.C.

30. Maidak, B. L., G. J. Olsen, N. Larsen, R. Overbeek, M. J. McCaughey, and C. R. Woese. 1996. The ribosomal database project. Nucleic Acids Res. 24:82-85.

31. Mesbah, M., U. Premachandran, and W. B. Whitman. 1989. Precise measurement of the $\mathrm{G}+\mathrm{C}$ content of deoxyribonucleic acid by high-performance liquid chromatography. Int. J. Syst. Bacteriol. 39:159-167.

32. Mueller, R. F., and P. H. Nielsen. 1996. Characterization of thermophilic consortia from two souring oil reservoirs. Appl. Environ. Microbiol. 62:3083 3087.

33. Ollivier, B., C. E. Hatchikian, G. Prensier, J. Guezennec, and J.-L. Garcia 1991. Desulfohalobium retbaense gen. nov., sp. nov., a halophilic sulfatereducing bacterium from sediments of a hypersaline lake in Senegal. Int. J Syst. Bacteriol. 41:74-81.

34. Ollivier, B., J.-L. Cayol, B. K. C. Patel, M. Magot, M.-L. Fardeau, and J.-L. Garcia. 1997. Methanoplanus petrolearius, sp. nov., a novel methanogenic bacterium from an oil-producing well. FEMS Microbiol. Lett. 147:51-56.

35. Pfennig, N., and F. Widdel. 1982. The bacteria of the sulphur cycle. Phil Trans. R. Soc. Lond. B298:433-441.

36. Ravot, G., M. Magot, M.-L. Fardeau, B. K. C. Patel, G. Prensier, A. Egan, J.-L. Garcia, and B. Ollivier. 1995. Thermotoga elfii sp. nov., a novel thermophilic bacterium from an African oil-producing well. Int. J. Syst. Bacteriol. 45:308-314

37. Ravot, G., M. Magot, B. Ollivier, B. K. C. Patel, E. Ageron, P. A. D. Grimont, P. Thomas, and J.-L. Garcia. 1997. Haloanaerobium congolense sp. nov., an anaerobic, moderately halophilic, thiosulfate- and sulfur-reducing bacterium from an African oil field. FEMS Microbiol. Lett. 147:81-88.

38. Redburn, A. C., and B. K. C. Patel. 1993. Phylogenetic analysis of Desulfotomaculum thermobenzoicum using polymerase chain reaction-amplified $16 \mathrm{~S}$ rRNA-specific DNA. FEMS Microbiol. Lett. 113:81-86.

39. Saiki, T., Y. Kobayashi, K. Kawagoe, and T. Beppu. 1985. Dictyoglomus thermophilus gen. nov., sp. nov., a chemoorganotrophic, anaerobic, thermophilic bacterium. Int. J. Syst. Bacteriol. 35:253-259.

40. Schauder, R., and A. Kröger. 1993. Bacterial sulphur respiration. Arch Microbiol. 159:491-497.

41. Stetter, K. O., and G. Gaag. 1983. Reduction of molecular sulphur by methanogenic bacteria. Nature 305:309-311.

42. Tardy-Jacquenod, C., P. Caumette, R. Matheron, C. Lanau, O. Arnauld, and M. Magot. 1996. Characterization of sulfate-reducing bacteria isolated from oil-field waters. Can. J. Microbiol. 42:259-266.

43. Wiegel, J., and L. G. Ljungdahl. 1981. Thermoanaerobacter ethanolicus gen. nov., sp. nov., a new extreme thermophilic, anaerobic bacterium. Arch. Microbiol. 128:343-348.

44. Winker, S., and C. R. Woese. 1991. A definition of the domains Archaea Bacteria and Eucarya in terms of small subunit ribosomal RNA characteristics. Syst. Appl. Microbiol. 13:161-165. 